\title{
Analysis of Sheep Lymphocyte Chromosomal Aberrations after Exposition to Chlortetracycline
}

\author{
Irena Šutiaková ${ }^{1}$, Václav Šutiak ${ }^{2}$, Mária Tulenková ${ }^{1}$ \\ ${ }^{1}$ Department of Biology, Faculty of Humanities and Natural Sciences, University of Prešov, Prešov, Slovak Republic; ${ }^{2}$ St. Elizabeth \\ University College of Health and Social Work, Bratislava, Slovak Republic. \\ Email: sutiakova@gmail.com
}

Received April 19 $9^{\text {th }}, 2013$; revised May $17^{\text {th }}, 2013$; accepted June $7^{\text {th }}, 2013$

Copyright (C) 2013 Irena Šutiaková et al. This is an open access article distributed under the Creative Commons Attribution License, which permits unrestricted use, distribution, and reproduction in any medium, provided the original work is properly cited.

\begin{abstract}
Tetracyclines are broad spectrum antibiotics and one type of various their compounds - chlortetracycline has been successfully used for our cytogenetic studies. We have selected for these studies the chromosomal assay because it is wellknown cytogenetic biomarker, which has been used to assess DNA damage at the chromosomal level. We analyzed the chromosomal aberrations and mitotic index in peripheral lymphocytes of sheep exposed by chlortetracycline chloride in pure tap water. To the food of the experimental group of animals $(\mathrm{à} \mathrm{n}=6)$ were added also $0.35 \mathrm{~g}$ of preparation Aureovit $12 \mathrm{C} 80$ plv. a. u. v. per kg b. w. and day (i.e. $168 \mathrm{mg}$ of chlortetracycline hydrochloride/kg b. w.) daily in food. The frequencies of aberrant cells $(\mathrm{ABC})$ in the experimental and control groups of sheep were stated to differ significantly $(\mathrm{P}=<0.001)$. In experimental group, chromatid breaks were the dominant type of chromosomal aberrations. No statistical differences in mitotic index values were found in the both groups $(\mathrm{P}>0.05)$. Increased frequencies of chromosome aberrations in peripheral lymphocytes of sheep exposed by chlortetracycline in food, suggested a potential hazard which needs the attention from the viewpoint of human and animal health. This knowledge is useful for all, for the human and veterinary medicine, as well as for the aquaculture. Many of these chlortetracycline substances for their environmental persistence and chemical unstability are present in the environment for various periods, and as a result, they are responsible for several effects on human and animal health through food chain.
\end{abstract}

Keywords: Antibiotics; Ovine Lymphocytes; Chromosomal Assay; Genotoxicity; Cytotoxicity; Health; Environment

\section{Introduction}

Tetracyclines (TCs) are broad spectrum antibiotics that have been successfully used worldwide in human and veterinary medicine (mainly for medical therapy of diseases) and in aquaculture [1-4]. However their effect may be significantly limited [5]. Many of these substances for their environmental persistence and chemical unstability, are present in the environment for long period, and as a result they are responsible for several effects on human and animal health through food chain [6]. TCs are known to possess limited stability on aqueous media and abiotic degradation products or reversible epimers may be formed through hydrolysis or photolysis, including epi-TCs and anhydro-TCs, as well as iso-TCs for chlortetracycline (CTC), [7,8]. Capleton et al. [9] proposed a method for veterinary medicine active ingredients according to estimates of their potential for indirect human exposure via the environment and their toxicity profile. Greater em- phasis was given to more serious health endpoints, such as carcinogenity and mutagenicity. Genotoxicity is the genetic damage, due to DNA damaging agents including drugs by different mechanisms. Cytotoxic and genotoxic properties of tetracycline. $\mathrm{HCl}$ (TC) have been studied in human fibroblast experiments and human peripheral lymphocytes [10-12].

Cytogenetic endpoints (chromosomal aberrations, micronuclei and sister chromatid exchanges) are most frequently used in hazard identification assays as the criterion in the risk assessment process [13-16]. It is necessary to investigate how TCs may affect target organisms-microorganisms and also non-target organisms. According to van der Schalie et al. [17], the use of nonhuman organisms, as early warning systems for human health risk is not new. Sentinel animal models could involve mammalian or non-mammalian species, domestic animals, or wildlife species. Sentinel animal populations would be exposed to a single chemical or a complex 
mixture, or to different media (e.g. air, water, soil, and sediment) in various locations.

CTC is usually administered in the feed or water for prophylactic and therapeutic purposes. To provide additional genotoxicity data, we studied the effect of chlortetracycline chloride (preparation Aureovit 12 C 80 plv. a.u.v.) in peripheral blood lymphocytes of sheep after its subchronical administration on the induction chromosomal aberrations, as cytogenetic endpoint.

\section{Materials and Methods}

\subsection{Experimental Animals and Nutrition}

In the experiment two-months old Slovak merino ewes weighing $15.2 \pm 1.05 \mathrm{~kg}$ were used. The animals were purchased from a private breeder. Prior to their inclusion in the experiments, they were nursed by mothers in such a way that they had limited access to drinking water and received no additional feed. Two weeks before the experiment the lambs were adapted to experimental housing conditions.

The animals were fed with the ČOJ-2 feeding mixture ration for animals and with meadow hay at doses of 250 $300 \mathrm{~g}$ of feeding mixture and $350 \mathrm{~g}$ dose of hay per each animal, respectively. Water was obtained at the "Východoslovenské vodárne a kanalizácie" enterprise in Košice, where chlorine levels and water $\mathrm{pH}$ were determined according to the valid standard STN 757111 [18]. For 30 days the lambs in the control group were given the same amounts of feed and water, they had been receiving during the adaptation period.

\subsection{Scheme of the Experiment}

The animals of the experimental group $(n=6)$ received the ČOJ-2 feeding mixture for animals and it was supplemented in this group only with chlortetracycline hydrochloride (preparation Aureovit 12 C 80 plv. a.u.v., containing $8 \%$ of the ingredient, $0.5 \mathrm{~kg}$ packaging) in such a way that each lamb consumed $0.35 \mathrm{~g}$ of the preparation per $\mathrm{kg}$ live weight (i.e. $168 \mathrm{mg}$ of chlortetracycline hydrochloride/kg b.w./day, added to the feeding mixture. The total quantity of the feeding mixture and meadow hay supplied was the same also in the control group (also $n=6$ animals), however without CTC.

\subsection{Lymphocyte Cultures}

After 30 days, blood samples were taken from jugular vein (v. jugularis) from each animal individually into glass tubes containing heparin (100 IU per ml blood). Heparinized blood $(0.4 \mathrm{ml})$ was cultured at $37.5^{\circ} \mathrm{C}$ for 48 h with $7.0 \mathrm{ml}$ chromosome medium S-chromo-cell supplemented with FCS, PHA, and L-glutamine (PAN Systems $\mathrm{GmbH}$, Biotechnologische Produkte, Germany).
Antibiotics were added to the culturing medium as follows: penicillin G $100 \mathrm{IU} / \mathrm{ml}$, streptomycin $100 \mu \mathrm{g} / \mathrm{ml}$ and $7.5 \% \mathrm{NaHCO}_{3}$. Two hours prior to harvest the cultures were treated with the spindle inhibitor colchicin (Fluka Biochemika) at the concentration of $10 \mu \mathrm{g} / \mathrm{ml}$ to arrest cells in metaphase. The squashes were stained with a $10 \%$ solution of Giemsa-Romanovski stain in phosphate buffer $(\mathrm{pH}=7.0)$.

\subsection{Cytogenetic Assay}

For each donor, 100 well spread metaphases were scored for chromosomal aberrations studies (magnification $1000 \times$ ) using microscope (Nikon). Images were taken by imaging microscopy (Nikon) using CCD-100 camera system (Mitsubishi). The images were processed using the Animal and Photostyler software system. The chromosomal aberrations were scored according to the classification criteria suggested by Savage [19]. The identification of the individual chromosome pairs was carried out according to the standardized karyotyping of the domestic sheep [20]. Chromatid breaks were distinguished from gaps when the centric piece was displaced with respect to the chromosome axis, or the size of the discontinuity exceeded the width of the chromatid. Gap aberrations were excluded from the total number of aberrations and considered separately. Chromosome exchanges were classified as stable (translocations, when detection was possible) and unstable (dicentric, ring and fragments).

\subsection{Mitotic Index}

In the chromosomal aberration study the mitotic index (MI) was evaluated by counting at least 1000 cells per treatment and dividing the number of splitting cells (metaphases) by the total number of cells.

\subsection{Statistical Evaluation of the Results}

The Sigma Stat program (Statistical software ${ }^{\text {TM }}$, Jandel Scientific) was employed for statistical evaluation of the results. The statistically significant differences between experimental and control groups were determined using analysis of variance (ANOVA) followed by Tukey test at the $95 \%$ confidence level.

\section{Results and Discussion}

The effect of CTC on the frequency of chromosome aberrations in peripheral lymphocytes of ewe lambs is summarized in Table 1. The experimental group of animals exhibited a significantly higher frequency of genetic damage $(20.50 \% \pm 5.24 \%$ aberrant cells) (ABC) compared to control group animals $(4.00 \% \pm 1.095 \%$ ABC; $\mathrm{P}$ $=<0.001$, ANOVA followed by Tukey test). In the experimental group, chromatid breaks were the dominant 
Table 1. Chromosomal aberrations in ewe lamb peripheral lymphocytes after treatment with high doses of chlortetracycline.

\begin{tabular}{|c|c|c|c|c|c|c|c|c|c|c|}
\hline \multirow{2}{*}{ Group } & \multirow{2}{*}{$\begin{array}{l}\text { No. of metap. } \\
\text { cell analyzed }\end{array}$} & \multicolumn{4}{|c|}{ Chromosomal aberrations } & \multirow{2}{*}{ Exchanges } & \multirow{2}{*}{ ABC \% } & \multirow{2}{*}{$\mathrm{B} / \mathrm{C}$} & \multirow{2}{*}{$\mathbf{G} / \mathbf{C}$} & \multirow{2}{*}{$\mathbf{M I}^{[29]}$} \\
\hline & & B1 & B2 & G1 & G2 & & & & & \\
\hline Cont. 1 & 100 & 3 & 2 & 1 & 0 & 0 & 5 & & & 1.103 \\
\hline 2 & 100 & 3 & 0 & 3 & 2 & 0 & 3 & & & 0.98 \\
\hline 3 & 100 & 1 & 3 & 0 & 0 & 0 & 3 & & & 1.203 \\
\hline 4 & 100 & 4 & 1 & 1 & 0 & 0 & 5 & & & 1.05 \\
\hline 5 & 100 & 4 & 1 & 1 & 0 & 0 & 5 & & & 0.932 \\
\hline 6 & 100 & 3 & 0 & 4 & 0 & 0 & 3 & & & 1.148 \\
\hline Mean & & 3.17 & 0.83 & 2.17 & 0.33 & 0.00 & 4.00 & 0.04 & 0.022 & 1.07 \\
\hline$\pm \mathrm{SD}$ & & 0.75 & 0.75 & 1.33 & 0.82 & & 1.095 & & & 0.10 \\
\hline \pm SEM & & 0.31 & 0.32 & 0.54 & 0.33 & & 0.45 & & & 0.42 \\
\hline Exper. 1 & 100 & 21 & 2 & 32 & 6 & 3 & 24 & & & 0.89 \\
\hline 2 & 100 & 18 & 1 & 26 & 4 & 0 & 18 & & & 1.06 \\
\hline 3 & 100 & 24 & 1 & 39 & 7 & 2 & 26 & & & 1.21 \\
\hline 4 & 100 & 15 & 1 & 23 & 7 & 2 & 17 & & & 0.96 \\
\hline 5 & 100 & 23 & 1 & 31 & 10 & 3 & 25 & & & 1.28 \\
\hline 6 & 100 & 13 & 1 & 29 & 5 & 2 & 13 & & & 1.13 \\
\hline Mean & & 19.00 & 1.17 & 30.00 & 6.50 & 2.00 & 20.50 & 0.24 & 0.36 & 1.09 \\
\hline$\pm \mathrm{SD}$ & & 4.43 & 0.41 & 5.51 & 2.07 & 1.09 & 5.24 & & & 0.15 \\
\hline \multirow[t]{2}{*}{ \pm SEM } & & 1.81 & 0.17 & 2.55 & 0.85 & 0.45 & 2.14 & & & 0.06 \\
\hline & & $=<0.001^{* !}$ & $=0.363^{\mathrm{ns}}$ & $=<0.001^{* !}$ & $=<0.001^{* !}$ & $=0.001^{*}$ & $=<0.001^{* !}$ & & & $=0.791^{\mathrm{ns}}$ \\
\hline
\end{tabular}

NS — no significant difference; ' statistical significance in ANOVA; 'statistical significance in Tukey test $(\mathrm{P}<0.05)$; SD—standard deviation; SEM-standard error mean; ABC - aberrant cells; B1, B2, G1, G2 = chromatid and chromosome breaks and gaps; B/C = number of breaks per cell; G/C = number of gaps per cell; Exper. $=$ experimental group; Control = cont. group; No. of metap. $=$ Number of methaphases; ${ }^{[29]}$ Preston et al., 1987.

type of aberrations $(19.00 \pm 4.43 ; \mathrm{P}=<0.001$, ANOVA followed by Tukey test). Most chemicals are S-dependent clastogens supporting the rise of chromatid-type aberrations. S-dependent mutagens exert the indirect effects on chromosomes in peripheral lymphocytes in vivo because replication occurrence only in stimulated cell cultures [21,22]. As shown in Table 1, in experimental group the frequencies of chromatid gaps $(\mathrm{P}=<0.001$, ANOVA followed Tukey test), chromosome gaps ( $\mathrm{P}=<$ 0.001 , ANOVA followed Tukey test) and exchanges ( $\mathrm{P}=$ 0.001 , ANOVA) were significantly higher than those in the control group. According to Brøgger [23] gaps are sensitive indicators of exposure to genotoxic drugs, they serve mainly at low doses as a "guard" parameter. On the other hand cells with chromosome aberrations may go on to become cancerous, and chromosome deletions and translocations are observed in most cancer cells [22,24]. Other aberrations were represented mainly by associations of acrocentric chromosomes.
The classic cytogenetic technique, without differential staining, permit a rapid overall analysis of tested cells and can detect most cells carrying the so-called unstable aberrations (chromosome and chromatid breaks, deletions, fragments, rings, dicentric and chromatid exchanges). Although these aberrations tend to have a lethal effect on the cells, it must be pointed out that other structural aberrations, the so-called stable aberrations, do not interfere with the division of chromosomes and allow the cell to survive $[25,26]$. The induction of DNA strand breaks and DNA repair were determined in human fibroblasts after treatment with tetracycline in the presence and absence of light. In all experiments human fibroblasts were more sensitive to incubations of TC in the light than in the dark. CTC induced single-strand breaks in isolated PM 2 DNA in the dark, however to a lower extent than in the presence of light [10]. Çelik and Eke [12] studied the genotoxic and cytotoxic effect of tetracycline on peripheral blood lymphocytes using micronucleus assay, SCE test 
and measuring mitotic activity and proliferation index (PRI) or/and nuclear division index (NDI) respectively in vitro. Their results indicated that tetracycline is able to induce both cytotoxic and moderate genotoxic effects in cultured human blood lymphocytes in vitro. No statistical differences were found in MI values in the groups (Table 1; $\mathrm{P}>0.05)$. Cellular proliferation is a phenomenon that may be causally associated with the induction of chromosomal damage for a number of compounds which are non-DNA reactive and thus are threshold in vitro clastogens [27]. Changes in biochemical biomarkers (antioxidant enzymes, catalase and superoxide dismutase) and DNA damage in soil on the earthworm Eisenia fetida exposed to tetracycline and chlortetracycline were investigated. Compared to enzyme activities, DNA damage as a biomarker was more sensitive and more suitable for detection low concentration exposure the genotoxicity of contaminants in terestrial environment [28]. The both antibiotics induced significant genotoxicity on earthworm Eisenia fetida in a dose - dependent manner $(\mathrm{P}<0.01)$.

\section{Conclusion}

On the whole, when we consider our results together with other published data our results demonstrate that chlortetracycline chloride (preparation Aureovit 12 C 80 plv. a.u.v.) induced a significant increase in chromosomal aberrations. These findings suggest a potential genotoxic hazard of this antibacterial drug as it may become capable of attacking the animal genetic material. In our experimental group of animals, chromatid breaks were the dominant type of chromosomal aberrations. Our experiences demonstrated that chromosomal damage studies may be used as the sensitive and effective biomarker procedure for detecting the genotoxicity effect of hazardous agents from the viewpoint of animal health. This is the argument also for the further studies and other examination especially in connection with the human health state because residues of hazardous agents in animal foodstuffs may be also their hazard factor.

\section{Acknowledgements}

This work was supported by the Grant Vega ME SR No. $1 / 0545 / 08$.

\section{REFERENCES}

[1] J. Sokol and E. Matisova, "Determination of Tetracycline Antibiotics in Animal Tissues of Food-Producing Animals by High-Performance Liquid Chromatography Using Solid-Phase Extraction," Journal of Chromatography, Vol. 669, No. 1-2, 1994, pp. 75-80. doi:10.1016/0021-9673(94)80338-2

[2] B. F. Kania, "Farmakologia Weterynaryjna Z Elementami Terapii. (Ed.), Wydawnictvo Lekarskie PZWL," Wars- zava, 2001.

[3] W. C. Andersen, J. E. Roybal, S. A. Gonzales, S. B. Turnipseed, A. P. Pfenning and L. R. Kuck, "Determination of Tetracycline Residues in Shrimp and Whole Milk Using Liquid Chromatography with Ultraviolet Detection and Residue Confirmation by Mass Spectrometry," Analytica Chimica Acta, Vol. 529, No. 1-2, 2005, pp. 145150. doi:10.1016/j.aca.2004.08.012

[4] D. Lin, Q. Zhou, Y. Xu, Ch. Chen and Y. Li, "Physiological and Molecular Responses of the Earthworm (Eisenia fetida) to Soil Chlortetracycline Contamination," Environmental Pollution, Vol. 171, 2012, pp. 46-51. doi:10.1016/j.envpol.2012.07.020

[5] V. Šutiak and I. Šutiaková, "Principal, Harmful and Side Effects of Drugs in Animals," Veterinary Journal Czech, Vol. 49, No. 2, 1999, pp. 77-81.

[6] E. Martínez-Carbalo, C. Gonzáles-Barreiro, S. Scharf and O. Gans, "Environmental Monitoring Study of Selected Veterinary Antibiotics in Animal Manure and Soils in Austria," Environmental Pollution, Vol. 148, No. 2, 2007, pp. 570-579. doi:10.1016/i.envpol.2006.11.035

[7] B. Halling-Sørensen, G. Sengeløv and J. Tjørnelund, "Toxicity of Tetracyclines and Tetracycline Degradation Products to Environmentally Relevant Bacteria, Including Selected Tetracycline-Resistant Bacteria," Archives of Environmental Contamination and Toxicology, Vol. 42, No. 3, 2002, pp. 263-271. doi:10.1007/s00244-001-0017-2

[8] B. Halling-Sørensen, A. Lykkeberg, F. Ingerslev, P. Blackwell and J. Tjørnelund, "Characterisation of the Abiotic Degradation Pathways of Oxytetracyclines in Soil Interstitial Water Using LC-MS-MS," Chemosphere, Vol. 50, No. 10, 2003, pp. 1331-1342. doi:10.1016/S0045-6535(02)00766-X

[9] A. C. Capleton, C. Courage, P. Rumsby, Ph. Holmes, E. Stutt, A. B. A. Boxall and L. S. Levy, "Priorisiting Veterinary Medicines According to Their Potential Indirect Human Exposure and Toxicity Profile," Toxicology Letters, Vol. 163, No. 3, 2006, pp. 213-223. doi:10.1016/j.toxlet.2005.10.023

[10] J. Witte, G. Oetken, C. Buschhfort and A. Hartman, "A Comparison of the DNA-Damaging, the Cytotoxic and Genotoxic Properties of Tetracycline in Human Fibrablasts in the Presence and Absence of Light," Mutation Research, Vol. 315, No. 1, 1994, pp. 33-40. doi:10.1016/0921-8777(94)90025-6

[11] A. Hartman, D. Wess and I. Witte, "Enhanced Cyto- and Genotoxicity of Tetracycline in Wilson Disease Fibroblasts," Mutation Research, Vol. 348, No. 1, 1995, pp. 712. doi:10.1016/0165-7992(95)90014-4

[12] A. Celik and D. Eke, "The Assessment of Cytotoxicity and Genotoxicity of Tetracycline Antibiotic in Human Blood Lymphocytes Using CBMN and SCE Analysis, in Vitro," International Journal of Human Genetics, Vol. 11, No. 1, 2011, pp. 23-29.

[13] J. D. Tucker and R. J. Preston, "Chromosome Aberrations, Micronuclei, Aneuploids Sister Chromatid Changes and Cancer Risk Assessment," Mutation Research, Vol. 365, No. 1-3, 1996, pp. 147-159. doi:10.1016/S0165-1110(96)90018-4 
[14] H. Norppa, S. Bonassi, I. L. Hansteen, L. Hagmar, U. Strömberg, P. Rössner, P. Boffetta, C. Lindholm, S. Gundy, J. Lazutka, A. Cebulska-Wasilewska, A. Fabiánová, R. J. Srám, L. E. Knudsen, L. Barale and A. Fucic, "Chromosomal Aberrations and SCEs as Biomarkers of Cancer Risk," Mutation Research, Vol. 600, No. 1-2, 2006, pp. 37-45. doi:10.1016/j.mrfmmm.2006.05.030

[15] M. Fenech, "Cytokinesis-Block Micronucleus Cytome Assays," Nature Protocols, Vol. 2, No. 5, 2007, pp. 10841104. doi:10.1038/nprot.2007.77

[16] C. Bolognesi, A. Creus, P. Ostrosky-Wegman and R. Marcos, "Review Micronuclei and Pescticide Exposure," Mutagenesis, Vol. 26, No. 1, 2011, pp. 19-26. doi:10.1093/mutage/geq070

[17] W. A. Van der Schalie, J. H. Gardner, J. A. Buntle, C. H. T. De Rosa, R. A. Finch, J. S. Reif, R. H. Reuter, L. C. Backer, J. Burger, L. C. Folmar and W. S. Stokes, "Animals as Sentinels of Human Health Hazards of Environmental Chemicals," Environmental Health Perpectives, Vol. 107, No. 4, 1999, pp. 309-315. doi:10.1289/ehp.99107309

[18] A. Laciaková, E. Bekeová, V. Hendrichovský, P. Turek and V. Laciak, "K Problematikevýskytu Chlóru v Pitnej Vode a Jeho Vplyv na Obsah Chloridov V Krvnom Sére," Hygiena, Vol. 44, 1999, pp. 78-84.

[19] J. R. K. Savage, "Classification and Relationships of Induced Chromosomal Structural Changes," Journal of $\mathrm{Me}$ dical Genetics, Vol. 12, 1975, pp. 103-122.

[20] D. Di Berardino, G. P. Di Moe, D. S. Gullagher, H. Hayes and I. Iannuzii, "ISCNDB International System for Chromosome Nomenclature of Domestic Bovids (Coordinator)," Cytogenetics Cell Genetics, Vol. 92, No. 3-4, 2001, pp. 283-299. doi:10.1159/000056917

[21] M. Sorsa, J. Wilbourn and H. Vainio, "Human Cytogenetic Damage as a Predictor of Cancer Risk," In: H. Vainio, P. N. Magee, D. B. McGregor and A. B. Mc Michael, Eds., Mechanisms of Carcinogenesis in Risk Identification, International Agency for Research on Cancer,
DARC, Lyon, 1992, pp. 543-554.

[22] G. Obe, P. Pfeiffer, J. R. K. Savage and J. C. Johannes, W. Goedecke, P. Jeppesen, A. T. Natarajan, W. Martinez-López, G. A. Folle and M. E. Drets, "Chromosomal Aberrations: Formation, Identification and Distribution," Mutation Research, Vol. 504, No. 1-2, 2002, pp. 17-36. doi:10.1016/S0027-5107(02)00076-3

[23] A. Brøger, "The Chromatid Gap-A Useful Parameter in Genotoxicology?" Cytogenetetics Cell Genetics, Vol. 33, No. 1-2, 1982, pp. 14-19. doi:10.1159/000131720

[24] N. McGranahan, R. A. Burell, D. Endesfelder, M. R. Novelli and Ch. Swanton, "Cancer Chromosomal Instability: Therapeutic and Diagnostic Challenges," EMBO Reports, Vol. 13, No. 6, 2012, pp. 528-538. doi:10.1038/embor.2012.61

[25] W. W. Au, "Monitoring Human Populations for Effects of Radiation and Chemical Exposures Using Cytogenetic Techniques," Occupational Medicine, Vol. 6, 1991, pp. 597-611.

[26] A. T. Natarajan and F. Palitti, "DNA Repair and Chromosomal Alterations," Mutation Research, Vol. 657, No. 1, 2008, pp. 3-7. doi:10.1016/j.mrgentox.2008.08.017

[27] L. Müller and P. Kasper, "Human Biological Relevance and the Use of Treshold-Arguments in Regulatory Genotoxicity Assessment: Experience with Pharmaceutical," Mutation Research, Vol. 464, No. 1, 2000, pp. 19-34. doi:10.1016/S1383-5718(99)00163-1

[28] L. Dong, J. Gao, X. Xie and Q. Zhou, "DNA Damage and Biochemical Toxicity of Antibiotics in Soil on the Earthworm Eisenia fetida," Chemosphere, Vol. 89, No. 1, 2012, pp. 44-51. doi:10.1016/j.chemosphere.2012.04.010

[29] R. J. Preston, B. J. Dean, S. Galloway, H. Holden, A. F. McFee and H Shelby, "Mammalian in Vivo Cytogenetic Assays: Analysis of Chromosome Aberration in Bone Marrow Cells," Mutation Research, Vol. 189, No. 2, 1987, pp. 157-165. doi:10.1016/0165-1218(87)90021-8 